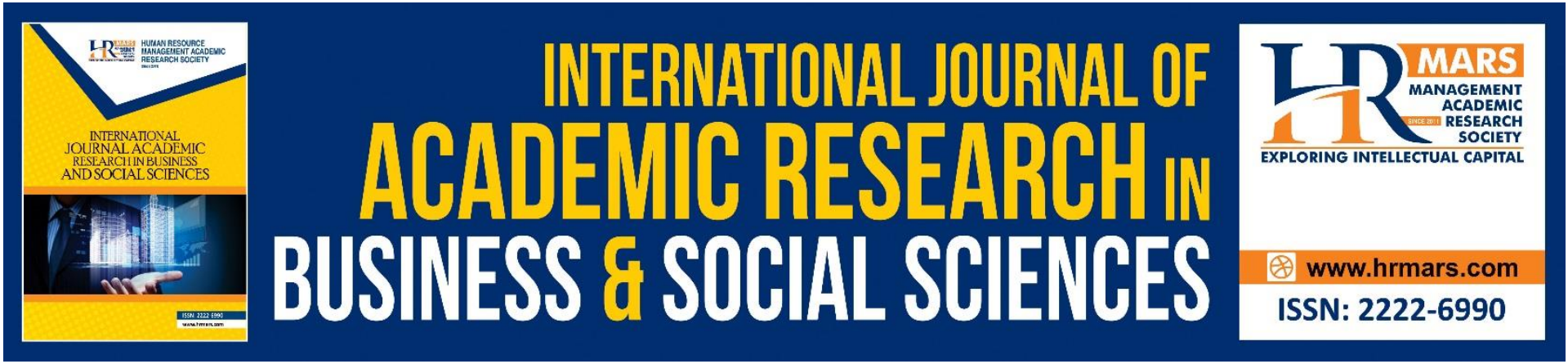

\title{
Enhancing Puppets' Roles for the Disaster Community
}

\section{Jane Teng Yan Fang, Loy Chee Luen \& Thuraiya Zakaria}

To Link this Article: http://dx.doi.org/10.6007/IJARBSS/v11-i1/9011～DOI:10.6007/IJARBSS/v11-i1/9011

Received: 04 December 2020, Revised: 06 January 2021, Accepted: 17 January 2021

Published Online: 28 January 2021

In-Text Citation: (Fang et al., 2021)

To Cite this Article: Fang, J. T. Y., Luen, L. C., \& Zakaria, T. (2021). Enhancing Puppets' Roles for the Disaster Community. International Journal of Academic Research in Business and Social Sciences, 11(1), 890-895.

Copyright: (C) 2021 The Author(s)

Published by Human Resource Management Academic Research Society (www.hrmars.com)

This article is published under the Creative Commons Attribution (CC BY 4.0) license. Anyone may reproduce, distribute, translate and create derivative works of this article (for both commercial and non-commercial purposes), subject to full attribution to the original publication and authors. The full terms of this license may be seen at: http://creativecommons.org/licences/by/4.0/legalcode

Vol. 11, No. 1, 2021, Pg. 890 - 895

http://hrmars.com/index.php/pages/detail/IJARBSS

JOURNAL HOMEPAGE

Full Terms \& Conditions of access and use can be found at http://hrmars.com/index.php/pages/detail/publication-ethics 


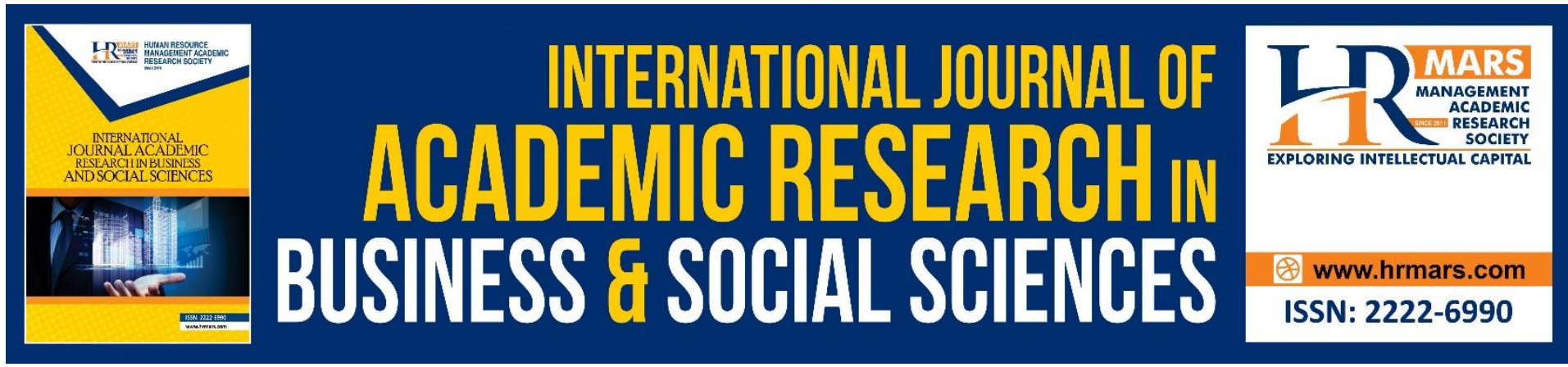

\title{
Enhancing Puppets' Roles for the Disaster Community
}

Jane Teng Yan Fang ${ }^{1}$, Loy Chee Luen² \& Thuraiya Zakaria ${ }^{3}$

1,3 Department of Entrepreneurship and Management, Faculty of Management and Entreprneurship, Universiti Pendidikan Sultan Idris, 35900 Tanjong Malim, Perak, Malaysia

${ }^{2}$ Department of Early Childhood Education, Faculty of Human Development, Universiti Pendidikan Sultan Idris, 35900 Tanjong Malim, Perak, Malaysia

\begin{abstract}
In the course of coping among the survivors during disasters, it is important for the community to seek comfort, trying to forget the pains, worries and problems of the disasters. Thus, being finding the strategies to cope are very important. Reports have shown puppets play significant roles in enabling those troubling experiences worked through more compassionately. The study investigated the roles of puppets in assisting the survivors to cope better in times of disasters. The study employed a qualitative paradigm where a total of six respondents were interviewed. The findings show through puppets' characters being played enabled disturbed thoughts and feeling to be clarified and the comfort served as a coping strategy. Besides that, the story lines create a sense of rooted-ness in time of disasters and help them to strengthen themselves to face the uncertainties. Consequently, the puppets stories generate sufficient make-believe to produce the effects of the psychological needs required at a particular occasion during disaster. Thus, this implies that the roles of puppets need to be enhanced and expanded among the disaster survivors.
\end{abstract}

Keywords: Puppets, Disaster, Coping Strategies.

\section{Introduction}

There has been a growing research attention for the coping strategies for the survivors during and after disasters. In capturing the learning experiences among survivors of the disasters, it was found to be paying more attention innately and getting comfort assistance as useful coping strategies. Thus, it is utmost important that the disaster community can be 'taken away' from the shock and worries. It was also reported (Jane, Qismullah \& Thuraiya, 2013; Selby \& Kagawa, 2012; Phil, 2006) by engaging them with meaningful activities could relax them even not totally forgetting their unfortunate feelings served as one of the coping strategies in time of disasters. At this time, theories of coping strategies stressed how to be effective within those particular occasions of the disaster (Wannachan, 2010). Specifically, puppets shows offer the individual a relationship built psychologically and strengthen oneself to help to cope during the disasters (Sabhanaz, 2017; Viklund, 2017). 


\section{Purpose of Research}

The purpose of study was to investigate the roles of puppets in assisting the survivors to cope better in times of disasters.

\section{Methodology}

The study employed a qualitative method in soliciting data. A total of six respondents were interviewed; two are males (i) Ramli (School head, age 54), and (ii) Yusof (Rehabilitation centre worker, age 49). The four females included (i) Rozaih (teacher, age 50), (ii) Mak K (care takers, age 55), (iii) Suhana (care taker, age 54), and (iv) Mak Su (survivor, age 47) among the disaster community. The respondents were selected purposely fully. It attempted to understand the extent, nature, problems and difficulties experienced by the disaster community. An in-depth interview, critical incident technique, participant observation and discourse analysis had also been adopted as methods to obtain relevant data within this strategy. For purpose of confidentiality, and adhering to the ethics on research, the actual names of the organizations and respondents were not used in this paper. The data obtained from all the six interviews were collectively analysed to uncover common themes and subthemes on roles of puppets for disaster community.

\section{Literature Review}

Studies on the roles of puppets through puppets shows or performances especially role playing have its own special appeal to comfort children. Puppets roles come in various forms and looks as humans, animals, and plants. The puppet performances can be done using the stage or without the stage. Other than that, the props, sound effect and lighting can be interwoven in puppet shows (Mirella, 2012; Loy, 2017). It is significant to use puppets within the community in the course of coping with the tragic of disaster.

Obviously, the studying of puppets and its roles should move from being static to being action oriented, story lines and stories of characters gradually started being viewed as a process; thus putting the focus on the interaction between the many survivors that occur within a setting of the disaster community benefits the survivors such as bringing calmness and relaxation moments during puppets shows (Loy, Nordin, Nor, Sopia, 2017; Muhammad, Kurnia, Tigo, Rini \& Hanggoro, 2016).

Since puppet shows has become an increasing important component in many disasters settings. In 2006, the International Federation in Yogyakarta suggests a more critical and reflexive approach to the study the roles of puppets in helping young survivors or children to cope during disasters. The development of more critical approaches of using puppets roles in disasters needs to adopt a more culturally sensitive and locally based interpretive approach, which takes accounts of an individual's experiences, social circle and its culture.

\section{Finding}

The results of the investigation towards the roles of puppets as strategies among the community of disasters are presented and discussed in this section. The social impacts are categorized into two sub themes: coping strategies and strengthening oneself spiritually in times of disaster (i) as coping strategies and (ii) strengthening oneself spiritually.

\section{(i) As coping strategies}

Nonetheless, in the stories telling through puppets enables an individual to describe or display how events are retrospectively experienced and to reflect on how then influences the now 
and it was found to be as one of the coping strategies among the survivors. As it was shared by the school head, Ramli:

We never know how the children can find calmness seeing the puppets shows....

It was shared that a generous capacity to tell and a warm capacity to listen support a comfortable fit within the community during disasters. The stories create sufficient coherence to facilitate talk about their confusions and desire to know why? And how? It was one of the way the survivors cope as recalled by teacher Roziah:

I really want to stop thinking about the disaster, the loss and everything. How? I think seeing the people come to tell stories and using some puppets helped us to relax and feel better.

The stories through the characters of puppets provided more than an intimate experience, they create a sense of rooted-ness and it strengthen oneself and helps to reduce the anxiety especially the uncertainty during the disaster. It serves as one of the best coping strategy. Survivor, Mak Su explained to:

And it is a group of us, we can also talk about our experience...it is good to be together under the show of puppets. Then immediately we can see everyone smile again and we can make our own stories...to use the puppets to play net time

\section{(ii) Strengthening oneself spiritually}

The phenomenon of emotional stressed and disturbed is obvious among the survivors of the disaster. Indirectly, the spirit and motivations were declined. As they felt loss and despair so they normally seek out for spiritual support. As it was shared by Yusof, worker at the Rehabilitation centre:

It so happens that I observe this spiritual thing a lot as many of us are lost, don't know what to do. We had been living a life so casual, so free, suddenly, we felt weak. So we started to seek to speak to ourselves, we speak to God, to look into ourselves more deeply.

Even though many aids were coming to them yet they did seek out to be reconnected with themselves so they could gain strength. Many of them were saying being able to see characters through puppets show who role play some of the significant features and scenes remind them to re-look into their life, values and belief.

Many a times, the puppets performances or stories give us strength and we can see now we did wrong last time and we have to change. Finding the strength is important as we can cope better. And help other people who are suffering too.... However, this is understandable since anybody can be affected during the disaster....

In short, they now began to pay more attention to their inner spirit after the disaster. Eventually, they become more connected to themselves and to God. Some reported they even changed their perspective towards life after the disaster. This 'incident' is shared by caretakers, Mak K and Suhana among the respondents.

The strengthening one-self in this sense explicates the situation by which survivors could seek opportunities of motivating them to be freed from the disturbances of disaster through the story telling or performances of puppets. The puppets shows which operate entertainment based on stories allowed the survivors to reconnect to themselves and seek spiritual strength through God and allowed them to yield different perspectives of life after being damaged by the disasters. 


\section{Discussion and Conclusion}

The uniqueness of puppets' roles in helping the survivors to cope and to gain strength is shown through the findings of this study. The aim is not to use puppets as the sole way to help survivors to go through the difficult times but to enable them to be able to forget the loss and despair for a certain time during the disasters. This requires all stakeholders who are dealing with disaster issues to broadening the context of disaster management and include puppets shows as part of the survivors coping strategies. In general, according to Mirella (2012); Loy (2017); Loy et al (2017), the roles and functions of the puppets are: (i) offer the opportunity to children to express themselves and (ii) encouraged children to explore their own feeling and relate them (iii) give the opportunity for the children to fantasise based on their imagination and (iv) evoke the sense of curiosity among children. It was revealed by the study, disasters caused lots of emotional pain and even traumatic episodes towards certain survivors. In overcoming the initial pain and loss, a short term coping strategy is utmost important. Besides, a relaxation time through puppets seemed possible to ease one's pain and re focus into their life again. It is felt it is important as to secure the quality of coping towards life and remain calm and peaceful throughout the disaster help reduce lots of burdens of keeping the survivors within the safe environment (Muhammad et al., 2016).

The study was found that the puppets' roles can be enhanced through its function as the coping strategy where survivors calmed down through watching the puppets show as a break from being burden by the disaster problems. The findings also revealed many of the survivors were saying being able to see characters through puppets show who role play some of the significant features and scenes remind them to re-look into their life, values and belief. Therefore, it is understood, puppets shows through its story line, characters and performances make significant contributions to calm and heal survivors during and after the disasters. In short, the findings add to the growing body of research on disaster specifically around the theme of coping strategies during disaster. Future research is needed to investigate the roles of puppets of other types of natural disasters in different settings.

\section{Acknowledgement}

The researchers would like to acknowledge the school head and teacher, worker, caretakers, and survivor from the rehabilitation centre to providing data and information for this research.

\section{Corresponding Author}

Dr. Jane Teng Yan Fang

Associate Professor Department of Management \& Leadership, Faculty of Management \& Economics Faculty of Human Development Universiti Pendidikan Sultan Idris Perak Malaysia

\section{References}

Jane, T. Y. F., Qismullah, Y., \& Thuraiya, Z. (2013). The learning experiences of the survivors and the schools rehabilitation from the tsunami in Aceh. Unpublished Research Report, Universiti Pendidikan Sultan Idris, Malaysia.

Loy, C. L., Nordin, M., Nor, M. R., \& Sopia, M. Y. (2017). Observation instrument to evaluate early childhood educator's teaching strategies using creative arts. International Journal of Academic Research in Business and Social Sciences, 7(4), 22226990.

Loy, C. L. (2017). puppets as pedagogical tools in social development and emotion of 
preschool children. Jurnal Pendidikan Awal Kanak-Kanak, 2017 (6), 45-56.

Mirella, F. A. (2012). The puppet's communicative potential as a mediating tool in preschool education. International Journal of Early Childhood, 44 (2), 171-184.

Muhammad, H. F., Kurnia, D. A., Tigo, M., Rini, K., \& Hanggoro, T. C. A. (2016).

Funny hand puppet story telling as a method of landslide introduction. Proceedings of the Kitakyushu International Conference. Natural Environment, Social Environment, Coexistence, Peace and Human Rights, Japan: Kitakyushu, 1-5.

Phil, V. (2006). Yogyakarta- Puppets and playtime bring comfort to quake's youngest survivors. Retrieved June 25, 2019, from https://ncdp.columbia.edu/micrositepage/resilient-children-ewsilient-communities/rcrc-preapredness-tools.

Sabhanaz, R. D., \& Busell, J. (2017). Disaster preparedness in Pakistan. Austin: Robert S. Strauss Centre.

Selby, D., \& Kagawa, F. (2012). Disaster Risk Reduction in School curricula: Case studies from thirty countries. Switzerland: United Nations Children Fund.

Viklund, A. (2017). Puppets in psychotherapy: An International web based study among clinicians. Sweden: UMEA University.

Wannachan, A. C. (2010). Living with disasters and changing climate : Children in Southeast Asian telling their stories about disaster and climate change. Thailand: Save the Children, Southeast Asia and the Pacific Regional Office. 